\title{
Use of cactus pear (Opuntia ficus indica Mill) replacing corn on carcass characteristics and non-carcass components in Santa Inês lambs ${ }^{1}$
}

\section{Tiago Ferreira Pinto 2,3 , Roberto Germano Costa $^{3}$, Ariosvaldo Nunes de Medeiros ${ }^{4}$, Geovergue Rodrigues de Medeiros ${ }^{3}$, Paulo Sergio de Azevedo ${ }^{4}$, Ronaldo Lopes Oliveira ${ }^{5}$, Israel Hernandez Treviño ${ }^{2}$}

\footnotetext{
1 Projeto financiado pelo IDR/Sisal - BA.

2 Mestrando em Zootecnia UFPB.

3 Instituto Nacional do Semiárido.

${ }^{4}$ Departamento de Zootecnia - UFPB.

${ }^{5}$ Departamento de Produção Animal - UFBA.
}

ABSTRACT - The objective of this study was to evaluate the biometric and morphometric measures, regional composition, carcass characteristics and non-carcass components of Santa Inês lambs submitted to levels of corn replaced by cactus pear in the diet. It was used 45 Santa Ines non-castrated male lambs, with average initial live weight of $25.50 \pm 0.48 \mathrm{~kg}$ as a completely randomized block design with five treatments $(0 ; 25 ; 50 ; 70$ and 100\%) and nine replicates. There was an effect of the diet on slaughter weight, empty body weight, hot and cold carcass, cold carcass weight, shoulder weight and loin weight. Cactus pear can replace up to $75 \%$ of corn in diets for feedlot Santa Inês lambs, without compromising production, carcass characteristics and production of non-carcass components.

Key Words: buchada, carcass dressing, production systems, retail cuts, semiarid

\section{Utilização da palma forrageira (Opuntia fícus-indica Mill) em substituição ao milho sobre as características de carcaça e componentes não constituintes da carcaça de cordeiros da raça Santa Inês}

\begin{abstract}
RESUMO - O objetivo neste trabalho foi avaliar as medidas biométricas e morfométricas, a composição regional, as características de carcaça e os componentes não constituintes da carcaça de cordeiros Santa Inês, submetidos a níveis de substituição do milho por palma forrageira na dieta. Foram utilizados 45 cordeiros não-castrados da raça Santa Inês com peso vivo inicial de 25,0 \pm 0,48 kg, distribuídos em delineamento de blocos ao acaso com cinco tratamentos (0; $25 ; 50 ; 75$ e 100\%) e nove repetições. Houve efeito da dieta sobre o peso ao abate, peso do corpo vazio, peso de carcaça quente e fria, peso da paleta e peso do lombo. A palma forrageira pode substituir até $75 \%$ do milho em dietas para cordeiros da raça santa Inês em confinamento, sem comprometer a produção, as características da carcaça e a produção de componentes não constituintes da carcaça.
\end{abstract}

Palavras-chave: buchada, cortes comerciais, rendimento de carcaça, semiárido, sistemas de produção

\section{Introduction}

Nutrition is an important factor that influences the quantitative characteristics of animal and carcass. However, in the semi-arid region of Brazil, the shortage of fodder in the dry season causes a drastic reduction of energy nutrients for animal maintenance and husbandry.

In sheep finishing, the use of concentrate is maximized in order to increase the energy density of diets, and corn is one of the major ingredients used as energy source. In northeastern Brazil, much of this corn is imported from other Brazilian regions reaching high values, which increases the production costs. Thus, an alternative would be to use an energy source less costly and available in the region (Melo et al., 2003).

Cactus pear is a viable alternative for sheep finishing due to its ability to store water and being adapted to environmental conditions of arid regions (Lüttge, 2004). With respect to its nutritional value, cactus pear is an excellent energy source, rich in minerals and vitamin $\mathrm{A}$. It has high concentration of non-fibrous carbohydrates (Wanderley et al., 2002) and total digestible nutrients (Melo et al., 2003).

This cactus has an average of $26 \%$ neutral detergent fiber (NDF); however, this component has low physical 
effectiveness, requiring the association of the cactus with roughage to correct the NDF in order to avoid ruminal disorders.

Regarding the quantitative carcass characteristics, the types of cuts made are determined by the consumer market, according to geographic region, customs and food habits of the population (Oliveira et al., 2002). The weight and yield of these cuts are influenced by nutrition plan, sex, weight, age (Clementino et al., 2007) and animal genotype (Mendonça et al., 2003).

The use of non-carcass components for the preparation of typical dishes such as sarapatel and buchada is common in northeastern Brazil (Medeiros et al., 2008). Within a meat production system, these components can provide high economic returns inasmuch as their marketing will add value to the activity, which make up to $30 \%$ of the animal (Carvalho et al., 2005).

The objective of this study was to evaluate the biometric and morphometric measures, carcass characteristics, and non-carcass components of Santa Inês lambs fed cactus pear in replacement to corn.

\section{Material and Methods}

The experiment was conducted at the Unidade de Pesquisa em Pequenos Ruminantes do Centro de Ciências Agrárias - CCA/UFPB, located at the municipality of São João do Cariri, PB, micro-region of Eastern Cariri, state of Paraíba, at coordinates $7^{\circ} 23^{\prime} 27^{\prime \prime} \mathrm{S}$ and $36^{\circ} 31^{\prime}$ 58" W. The local climate is classified as Bsh (hot semiarid) according to
Köppen classification. Forty-five non-castrated Santa Ines male lambs with average weight of $25.50 \pm 0.48 \mathrm{~kg}$ were used, confined individually in stalls provided with feed box and drinking trough where they received the experimental diets. The animals were weighed, identified, treated against ecto and endoparasites and vaccinated against clostridial diseases. The weighings occurred every seven days, starting from the beginning of the experiment until slaughter.

The ingredients used were Tifton hay (Cynodum $s p$ ), soybean meal, corn, wheat bran, limestone, mineral and cactus pear. Diets (Table 1) were formulated to meet the requirements of sheep of $25 \mathrm{~kg}$ of LW and daily gain of $250 \mathrm{~g} /$ day (NRC, 1985). The treatments consisted of the replacement of corn by cactus pear (Opuntia ficus-indica Mill) at increasing levels: $\mathrm{T} 1=0 \%, \mathrm{~T} 2=25 \%, \mathrm{~T} 3=50 \%, \mathrm{~T} 4=$ $75 \%, \mathrm{~T} 5=100 \%$. Experimental diets were offered twice daily in the form of complete mixture. The dry matter intake (DMI) was determined by daily measurements of received and rejected food, so as to provide daily surplus of about $10 \%$.

Body measures were obtained by using methodology described by Osório et al. (1998). The animals remained standing on a flat surface, avoiding movement, to be measured with the aid of tape measure and compass. The following measurements were performed: withers height and hip height, body length, chest circumference, leg length, chest width.

Upon reaching approximately $35 \mathrm{~kg}$ of live weight (LW), the animals were weighed, thus obtaining the final weight (FW) and submitted to solid fasting of 12 hours. After this period, the animals were weighed again to obtain the slaughter weight (SW) in order to determine the percentage

Table 1- Percentage composition of ingredients in diets (\% DM) and in the ration according to the cactus pear levels

\begin{tabular}{|c|c|c|c|c|c|}
\hline \multirow[t]{2}{*}{ Ingredient (\%DM) } & \multicolumn{5}{|c|}{ Substitution levels (\%) } \\
\hline & 0 & 25 & 50 & 75 & 100 \\
\hline Cactus pear & 0.00 & 7.00 & 14.00 & 21.00 & 28.00 \\
\hline Ground corn & 28.0 & 21.0 & 14.0 & 7.0 & 0.00 \\
\hline Soybean meal & 17.60 & 17.60 & 17.60 & 17.60 & 17.60 \\
\hline Wheat bran & 11.40 & 11.40 & 11.40 & 11.40 & 11.40 \\
\hline Tifton hay & 40.0 & 40.0 & 40.0 & 40.0 & 40. 0 \\
\hline Mineral salt & 1.5 & 1.5 & 1.5 & 1.5 & 1.5 \\
\hline Limestone & 1.5 & 1.5 & 1.5 & 1.5 & 1.5 \\
\hline \multicolumn{6}{|l|}{ Composition of feed \% in the DM } \\
\hline Dry Matter (DM) & 89.46 & 59.34 & 44.40 & 35.46 & 29.52 \\
\hline Organic matter & 90.72 & 89.93 & 89.14 & 88.35 & 87.56 \\
\hline Mineral matter & 5.11 & 5.84 & 6.56 & 7.28 & 8.00 \\
\hline Crude protein & 16.24 & 15.91 & 15.57 & 15.23 & 14.89 \\
\hline Ether extract & 2.38 & 2.25 & 2.11 & 1.98 & 1.85 \\
\hline Neutral detergent fiber (NDF) & 42.60 & 43.98 & 45.36 & 46.74 & 48.12 \\
\hline Acid detergente fiber (ADF) & 20.32 & 21.54 & 22.77 & 23.99 & 25.21 \\
\hline Total carbohydrates (TC) & 76.27 & 76.00 & 75.76 & 75.51 & 75.26 \\
\hline Non-fibrous carbohydrates (NFC) & 37.94 & 36.15 & 34.39 & 32.62 & 30.84 \\
\hline Total digestible nutrients (TDN) ${ }^{1}$ & 63.88 & 62.15 & 60.42 & 58.69 & 56.95 \\
\hline Metabolizable energy (Mcal/kg of DM) & 2.30 & 2.24 & 2.18 & 2.12 & 2.05 \\
\hline
\end{tabular}

${ }^{1} \mathrm{TDN}(\%)=(\mathrm{DCP}+\mathrm{DNDF} \mathrm{CP}+\mathrm{DNFC}+(\mathrm{DEE} \times 2.25)-7)$, equation proposed by Weiss (1999). 
of weight loss due to fasting (FW), which was calculated as follows: $\mathrm{FW} \%=(\mathrm{LW}-\mathrm{SW}) \times 100 / \mathrm{LW}$.

Prior to slaughter, the body condition was subjectively determined by palpation on the lumbar region, right after the $13^{\text {th }}$ pair of ribs, assigning score from 1.0 to 5.0 according to definitions of César \& Souza (2007).

At slaughter, the animals were stunned by concussion in the atlanto-occipital region, followed by bleeding for three minutes through the section of the carotid artery and jugular vein. The blood was collected in tared container for 3 minutes for subsequent weightings. Then, the animals were skinned and eviscerated to obtain the edible and non-carcass components which were used in the preparation of buchada as follows (blood, tongue, lungs, heart, liver, spleen, kidney, empty gastrointestinal tract omentum, head and paw), as described by Costa et al. (2007).

Subsequently, head (section in the atlanto-occipital joint), paws (section in the carpal and tarsal-metatarsal joints) and tail were removed. Then, the hot carcass (HCW), including kidney and renal pelvic-fat, were weighed. The gastrointestinal tract (GIT) was weighed full and empty to determine the empty body weight (EBW), which was used to determine the biological or true yield [TY,\% = (HCW / EBW × 100)], according to Cezar \& Souza (2007).

The carcasses were chilled for 24 hours $\pm 4^{\circ} \mathrm{C}$ in cold chamber, with tarsal-metatarsal joints spaced at $14 \mathrm{~cm}$ by means of hooks. After this period, they were weighed to obtain the cold carcass weight (CCW) and calculation of the loss by cooling [LC, $\%=(\mathrm{HCW}-\mathrm{CCW}) / \mathrm{HCW} \times 100]$. Then, it was removed kidneys and pelvic + renal fat, whose weights were recorded and subtracted from the hot and cold carcass weight. The hot carcass dressing $(\mathrm{HCD}, \%=\mathrm{HCW} / \mathrm{SW} \times 100)$ and cold carcass dressing yield $(\mathrm{CCD}, \%=\mathrm{CCW} / \mathrm{SW} \times 100)$ were also calculated.

Before the linear and carcass section measurements, subjective evaluation was conducted to determine the carcass conformation, by assigning scores from 1.0 to 5.0 (1.0 for the worst and 5.0 for the best conformation), according to methodology described by Colomer-Rocher et al. (1988). Prior the carcass section, the following morphometric measures were taken: carcass external length; carcass internal length, leg length, thigh circumference, hip circumference, hip width, chest depth and carcass conformation. The Carcass Compactness index (CC) was defined by the cold carcass weight / cold carcass internal length ratio.

After taking the internal and external measures, half right and left carcasses were split into five anatomical regions (retail cuts) using methods described by ColomerRocher et al. (1988), considering the following cuts: neck, shoulder, rib, loin and leg.
The individual weights of each cut were recorded to calculate their proportion in relation to the average halfcarcasses and to obtain the commercial yield of cuts. The rib eye area (REA) was measured in the Longissimus dorsi muscle between the $12^{\text {th }}$ and $13^{\text {th }}$ ribs of the left half carcass. The muscle contour was outlined on plastic sheet and the area was determined through a digital planimeter, using the mean of three readings. The fat thickness measurement was obtained in the L. dorsi muscle through digital caliper.

The experimental design used was randomized blocks with five treatments and nine replicates, and the blocks were formed according to the initial weight of animals. Besides the analysis of variance, regression analysis was performed in function of the substitution level of corn by cactus pear in the diet. The criteria used to select the equations were biological behavior, determination coefficient $\left(r^{2}\right)$ and significance levels ( 1 and 5\% probability) for the regression parameters obtained by the t-Student test. Statistical analysis was performed by using the SAEG computer program(2001).

\section{Results and Discussion}

Biometric measurements (Table 2) were not affected $(\mathrm{P}>0.05)$ by the inclusion of cactus pear in diets. These results confirm that these measures are not influenced by nutritional management, provided the animals are slaughtered with the same final weight (Rosa et al., 2002).

Body length $(64.47 \mathrm{~cm})$, withers height $(65.35 \mathrm{~cm})$, hip height $(67.71 \mathrm{~cm})$, chest width $(19.27 \mathrm{~cm})$, leg length $(32.94 \mathrm{~cm})$ hip width $(17.66 \mathrm{~cm})$ values suggest measurements of compact animals. Body condition score (3.32) was considered very good, considering the genotype studied. The body score indicates the amount of muscle and adipose tissue in relation to the bone mass proportion. This indicates the best time for slaughtering the animals.

The carcass morphometric measurements were not affected $(\mathrm{P}>0.05)$ by the substitution of corn by cactus pear in the diet of lambs (Table 3). These results are related to weight established for slaughter ( $\pm 33 \mathrm{~kg}$ ). For diets with 75 and $100 \%$ of cactus pear, the slaughter weight and therefore the cold carcass weight slightly reduced compared to other levels used, slightly affecting the carcass conformation. The carcass conformation level had an average score of 2.89 , which is considered satisfactory.

Carcass compactness (CC) was not influenced by diet ( $P>0.05)$, showing mean value of $0.23 \mathrm{~kg} / \mathrm{cm}$. The $\mathrm{CC}$ found in this study showed significant values, indicating good 
deposition of muscle tissue per unit of carcass length. In absolute terms, it was observed that the CC of lambs fed 75 and $100 \%$ of cactus pear were slightly lower than those fed with the other diets. This occurs in response to the lower cold carcass weights due to the increased levels of cactus pear in the diet.

Slaughter weight decreased linearly $(\mathrm{P}<0.05)$ with the substitution of corn by cactus pear (Table 4). Consequently, there was also a decrease $(\mathrm{P}<0.05)$ of empty body weight (EBW), hot carcass weight (HCW) and cold carcass weight (CCW). The increased levels of substitution of corn by cactus pear caused a reduction in energy density of diets, which ranged from 2.3 to $2.05 \mathrm{Mcal} / \mathrm{kg} \mathrm{DM}$, and other nutrients, influencing the development and tissue deposition of lambs.

Energy consumption level can change the partition to use this energy for the synthesis of protein or lipids, or in terms of tissues, in the development of muscle and adipose tissue (Ferreira et al., 1998). For the NRC (1985), for each kilogram of gain in empty body weight, there is a requirement of 1.2 Mcal of metabolizable energy for protein and water deposition and 8.0 Mcal of metabolizable energy for fat and water deposition.

Table 2 - Biometric measures of Santa Inês lambs fed increasing levels of cactus pear in diets

\begin{tabular}{|c|c|c|c|c|c|c|c|}
\hline \multirow[t]{2}{*}{ Variable } & \multicolumn{5}{|c|}{ Substitution level (\%) } & \multirow[t]{2}{*}{$\mathrm{X}$} & \multirow[t]{2}{*}{$\mathrm{CV}(\%$} \\
\hline & 0 & 25 & 50 & 75 & 100 & & \\
\hline Corporal length ,cm & 62.72 & 64.67 & 63.83 & 64.22 & 66.94 & $64.47 \mathrm{~ns}$ & 6.51 \\
\hline Withers height $(\mathrm{cm})$ & 65.11 & 64.56 & 66.28 & 64.89 & 65.78 & $65.32 \mathrm{~ns}$ & 4.66 \\
\hline Hind height $(\mathrm{cm})$ & 67.22 & 67.33 & 68.50 & 67.78 & 67.72 & $67.71 \mathrm{~ns}$ & 4.42 \\
\hline Thoracic width (cm) & 19.11 & 19.61 & 19.28 & 19.50 & 18.84 & $19.27 \mathrm{~ns}$ & 5.58 \\
\hline Leg length $(\mathrm{cm})$ & 32.78 & 32.89 & 33.00 & 32.83 & 33.22 & $32.94 \mathrm{~ns}$ & 3.39 \\
\hline Thoracic perimeter $(\mathrm{cm})$ & 69.44 & 69.56 & 70.44 & 70.33 & 70.11 & $69.98 \mathrm{~ns}$ & 3.79 \\
\hline Hind width $(\mathrm{cm})$ & 17.94 & 17.33 & 17.17 & 17.83 & 18.00 & $17.66 \mathrm{~ns}$ & 7.29 \\
\hline Leg perimeter (cm) & 31.67 & 32.56 & 32.67 & 32.67 & 32.45 & $32.40 \mathrm{~ns}$ & 7.34 \\
\hline Body condition (1-5) & 3.41 & 3.39 & 3.36 & 3.25 & 3.19 & $3.32 \mathrm{~ns}$ & 13.19 \\
\hline
\end{tabular}

ns - $(\mathrm{P}>0.05), \mathrm{X}=$ average; $\mathrm{CV}=$ coefficient of variation.

Table 3 - Carcass morphometric measurements of Santa Inês lambs according to the cactus pear levels in diets

\begin{tabular}{|c|c|c|c|c|c|c|c|}
\hline \multirow[t]{2}{*}{ Variable } & \multicolumn{5}{|c|}{ Substitution level (\%) } & \multirow[t]{2}{*}{$\mathrm{X}$} & \multirow[t]{2}{*}{ CV $(\%$} \\
\hline & 0 & 25 & 50 & 75 & 100 & & \\
\hline Internal carcass lenght $(\mathrm{cm})$ & 62.68 & 62.89 & 62.83 & 62.33 & 62.78 & $62.7 \mathrm{~ns}$ & 3.24 \\
\hline Leg length $(\mathrm{cm})$ & 41.78 & 41.22 & 41.78 & 42.11 & 41.89 & $41.96 \mathrm{~ns}$ & 2.87 \\
\hline Leg perimeter (cm) & 28.50 & 27.89 & 28.00 & 27.39 & 27.00 & $27.75 \mathrm{~ns}$ & 7.16 \\
\hline Hind perimeter $(\mathrm{cm})$ & 52.78 & 52.33 & 54.33 & 51.83 & 51.22 & $52.50 \mathrm{~ns}$ & 7.08 \\
\hline Hind width $(\mathrm{cm})$ & 21.03 & 18.72 & 19.14 & 19.89 & 17.11 & $19.18 \mathrm{~ns}$ & 18.40 \\
\hline Thoracic depth (cm) & 27.17 & 26.89 & 27.67 & 27.33 & 27.11 & $27.23 \mathrm{~ns}$ & 4.45 \\
\hline Thoracic perimeter (cm) & 68.56 & 69.50 & 68.94 & 68.00 & 68.72 & $68.74 \mathrm{~ns}$ & 3.3 \\
\hline Conformation grade (1-5) & 3.00 & 3.11 & 3.22 & 2.44 & 2.67 & $2.89 \mathrm{~ns}$ & 41.57 \\
\hline Carcass compactness $(\mathrm{kg} / \mathrm{cm})$ & 0.24 & 0.24 & 0.24 & 0.23 & 0.23 & $0.23 \mathrm{~ns}$ & 6.98 \\
\hline
\end{tabular}

ns - $(\mathrm{P}>0.05), \mathrm{X}=$ average; $\mathrm{CV}=$ coefficient of variation.

Table 4 - Carcass characteristics of Santa Inês lambs according to the cactus pear level in the diet

\begin{tabular}{|c|c|c|c|c|c|c|c|c|}
\hline \multirow[t]{2}{*}{ Variable } & \multicolumn{5}{|c|}{ Substitution level (\%) } & \multirow[t]{2}{*}{ CV (\%) } & \multirow[t]{2}{*}{ Regression } & \multirow[t]{2}{*}{$\mathrm{r}^{2}$} \\
\hline & 0 & 25 & 50 & 75 & 100 & & & \\
\hline Final weight (kg) & 35.88 & 35.77 & 35.91 & 36.04 & 35.22 & 3.49 & $\mathrm{Y}=35.76^{\mathrm{ns}}$ & - \\
\hline Slaughter weight (kg) & 33.82 & 33.41 & 33.00 & 32.59 & 32.18 & 4.53 & $\mathrm{Y}=33.82-0.016 * \mathrm{P}$ & 0.72 \\
\hline Empty body weight (kg) & 29.63 & 29.18 & 28.73 & 28.28 & 27.82 & 3.87 & $\mathrm{Y}=28.63-0.018 * * \mathrm{P}$ & 0.71 \\
\hline Hot carcass weight (kg) & 15.50 & 15.25 & 15.00 & 14.75 & 14.50 & 6.21 & $\mathrm{Y}=15.50-0.010 * \mathrm{P}$ & 0.59 \\
\hline Cold carcass weight (kg) & 15.15 & 14.95 & 14.75 & 14.55 & 14.35 & 5.38 & $\mathrm{Y}=15.15-0.008 * \mathrm{P}$ & 0.53 \\
\hline Hot carcass yield (\%) & 45.73 & 46.15 & 46.30 & 46.20 & 46.84 & 5.64 & $\mathrm{Y}=46.24 \mathrm{~ns}$ & - \\
\hline Cold carcass yield (\%) & 44.80 & 44.77 & 44.74 & 44.71 & 44.68 & 5.70 & $\mathrm{Y}=44.74 \mathrm{~ns}$ & - \\
\hline Biological or true yield (\%) & 51.84 & 53.98 & 52.48 & 52.53 & 53.35 & 4.05 & $\mathrm{Y}=52.81 \mathrm{~ns}$ & - \\
\hline Cooling losses (\%) & 2.25 & 1.96 & 1.66 & 1.36 & 1.03 & 5.82 & $\mathrm{Y}=2.25-0.0116 * \mathrm{P}$ & 0.63 \\
\hline Fasting losses (\%) & 5.94 & 6.66 & 7.38 & 8.09 & 8.81 & 24.26 & $\mathrm{Y}=5.94+0.028 * * \mathrm{P}$ & 0.89 \\
\hline Rib eye area $\left(\mathrm{cm}^{2}\right)$ & 10.66 & 10.41 & 10.92 & 9.73 & 10.05 & 11.20 & $\mathrm{Y}=10.35 \mathrm{~ns}$ & - \\
\hline Fat thickness (mm) & 0.756 & 0.739 & 0.648 & 0.711 & 0.729 & 39.88 & $\mathrm{Y}=0.715 \mathrm{~ns}$ & - \\
\hline
\end{tabular}

ns: $(\mathrm{P}>0.05) ; *(\mathrm{P}<0.05) ; * *(\mathrm{P}<0.01) ; \mathrm{X}=$ average; $\mathrm{CV}=$ coefficient of variation. 
Hot carcass dressing, cold carcass dressing and biological yield were not affected $(\mathrm{P}>0.05)$ by the addition of cactus pear in the diet.

The loss by cooling arising from loss of moisture during cold storage were influenced $(\mathrm{P}<0.05)$ by experimental treatments. The average found was $1.65 \%$, which is considered normal according to literature (Araújo Filho et al., 2007). The average for sheep is $2.5 \%$, with a range of variation from 1 to $7 \%$. These variations were due to genotype, sex, fat cover, temperature and humidity in the cold chamber.

The rib eye area (REA) was not affected $(\mathrm{P}>0.05)$ by the addition of cactus pear in the diet, with mean value of $10.35 \mathrm{~cm}^{2}$. Rib eye area is used to predict the amount of carcass muscle because of its high correlation with the proportion of muscle. However, studies have shown that this variable should be used with other traits to better evaluate the carcass muscle composition (Silva \& Pires, 2000).

A linear decreasing effect was obtained for the halfcarcass $(\mathrm{P}<0.05$; Table 5$)$. This behavior was expected, as it is a representation of $50 \%$ of the total cold carcass weight that also presented linear decreasing effect.

The weights of cuts were not affected $(\mathrm{P}>0.05)$ by the substitution of corn by cactus pear in the diet, nor were their respective yields (Table 5), except for shoulder and loin weights, which showed linear decreasing behavior $(\mathrm{P}<0.05)$.

The leg, which is considered one of the prime cuts of lamb carcass, showed average weight of $2.39 \mathrm{~kg}$ and in relative terms, contributed with the highest yield (32.56\%). These values are due to the greater amount of muscle tissue in this cut in relation to other anatomical regions of the carcass.
The sum of the yields of leg, loin and shoulder was $59.37 \%$. Silva Sobrinho et al. (2005) reported that in sheep breeds for meat production, this sum must show a minimum value of $60 \%$. The value found in the present study demonstrates that Santa Ines lambs fed different cactus pear levels in diets showed values close to those of more specialized breeds for meat production.

It is observed minimal numerical differences among treatments (Table 5). This similarity can be enhanced by the law of anatomical harmony by Boccard \& Dumont (1960) which reports that in carcasses with similar weight and amounts of fat, almost all regions of the body are found in similar proportions, regardless of the conformation of the genotype studied.

There was no significant effect $(\mathrm{P}>0.05)$ of the inclusion of cactus pear on the non-carcass components, sum of the "buchada" components and "buchada" yield in relation to the slaughter weight (Table 6).

The use of organs and viscera in the development of products such as "buchada", which is a typical dish in northeastern Brazil, represents an important economic alternative (Costa et al., 2006). To prepare this dish, blood, liver, kidneys, lungs, spleen, tongue, heart and part of the omentum are used, as well as rumen, reticulum and empty GIT, except for large intestine. In some places, head without the mandibles and paws are also included. All these components are submitted to a rigorous cleaning and pre-cooking process, for better food safety (Medeiros et al., 2008).

The total weight of non-carcass components used in the preparation of "Buchada" was (5.84 kg), which represents about $17.7 \%$ of the slaughter weight of Santa Ines lambs fed different cactus pear levels in the diet.

Table 5 -Weight and yield of retail cuts of Santa Inês lambs according to the cactus pear levels in the diet

\begin{tabular}{|c|c|c|c|c|c|c|c|c|}
\hline Variable & \multicolumn{5}{|c|}{ Substitution level (\%) } & CV (\%) & Regression & $\mathrm{r}^{2}$ \\
\hline Half cold carcass weight (kg) & 7.56 & 7.46 & 7.36 & 7.25 & 7.15 & 5.52 & $\mathrm{Y}=7.56-0.004 * \mathrm{P}$ & 0.58 \\
\hline Neck ( kg) & 0.87 & 0.87 & 0.87 & 0.87 & 0.86 & 9.13 & $\mathrm{Y}=0.870 \mathrm{~ns}$ & - \\
\hline Loin $(\mathrm{kg})$ & 0.60 & 0.58 & 0.57 & 0.56 & 0.55 & 9.47 & $\mathrm{Y}=0.602-0.00055^{*} \mathrm{P}$ & 0.54 \\
\hline Leg (kg) & 2.44 & 2.42 & 2.39 & 2.36 & 2.34 & 5.69 & $\mathrm{Y}=2.392 \mathrm{~ns}$ & - \\
\hline Shoulder (kg) & 18.91 & 18.96 & 19.00 & 19.05 & 19.10 & 3.82 & $\mathrm{Y}=19.01 \mathrm{~ns}$ & - \\
\hline Neck ( kg) & 10.21 & 10.33 & 10.44 & 10.56 & 10.68 & 8.73 & $\mathrm{Y}=10.44 \mathrm{~ns}$ & - \\
\hline Loin $(\mathrm{kg})$ & 7.78 & 7.97 & 7.98 & 7.80 & 7.44 & 6.53 & $\mathrm{Y}=7.80 \mathrm{~ns}$ & - \\
\hline Leg $(\mathrm{kg})$ & 32.32 & 32.43 & 32.55 & 32.66 & 32.78 & 3.29 & $\mathrm{Y}=32.56 \mathrm{~ns}$ & - \\
\hline Ribs (kg) & 27.22 & 27.28 & 27.33 & 27.39 & 27.44 & 4.36 & $\mathrm{Y}=27.33 \mathrm{~ns}$ & - \\
\hline
\end{tabular}


Table 6 - Weight of non-carcass components and "buchada" yield in function of the different cactus pear levels in the diet

\begin{tabular}{|c|c|c|c|c|c|c|c|}
\hline \multirow[t]{2}{*}{ Variable } & \multicolumn{5}{|c|}{ Substitution level (\%) } & \multirow[t]{2}{*}{$\mathrm{X}$} & \multirow[t]{2}{*}{ CV $(\%)$} \\
\hline & 0 & 25 & 50 & 75 & 100 & & \\
\hline Blood (kg) & 1.59 & 1.57 & 1.45 & 1.38 & 1.48 & $13.49 \mathrm{~ns}$ & 13.85 \\
\hline Spleen (kg) & 0.09 & 0.08 & 0.08 & 0.08 & 0.07 & $0.08 \mathrm{~ns}$ & 19.73 \\
\hline Heart（kg） & 0.23 & 0.22 & 0.21 & 0.21 & 0.22 & $0.22 \mathrm{~ns}$ & 12.14 \\
\hline Lungs (kg) & 0.41 & 0.38 & 0.39 & 0.42 & 0.39 & $0.40 \mathrm{~ns}$ & 19.16 \\
\hline Liver(kg) & 0.65 & 0.63 & 0.63 & 0.64 & 0.61 & $0.63 \mathrm{~ns}$ & 9.75 \\
\hline Tongue (kg) & 0.11 & 0.11 & 0.11 & 0.11 & 0.10 & $0.11 \mathrm{~ns}$ & 16.45 \\
\hline Kidneys (kg) & 0.10 & 0.10 & 0.10 & 0.10 & 0.10 & $0.10 \mathrm{~ns}$ & 10.98 \\
\hline Empty GIT $(\mathrm{kg})^{1}$ & 2.39 & 2.32 & 2.69 & 2.58 & 2.58 & $2.51 \mathrm{~ns}$ & 1.99 \\
\hline Omentum fat (kg) & 0.34 & 0.29 & 0.26 & 0.29 & 0.25 & 0.99ns & 37.94 \\
\hline$\Sigma$ “Buchada" $(\mathrm{kg})^{2}$ & 5.92 & 5.71 & 5.92 & 5.84 & 5.81 & $5.84 \mathrm{~ns}$ & 5.64 \\
\hline Buchada:SW (\%) ${ }^{3}$ & 17.50 & 17.10 & 17.94 & 17.92 & 18.05 & $17.70 \mathrm{~ns}$ & 8.83 \\
\hline
\end{tabular}

ns $=(\mathrm{P}>0.05)$

${ }^{1}$ Empty GIT, rumen, reticulum, omasum, abomasum, large and small intestine.

$2 \Sigma$ “Buchada" components (edible offals), sum of blood, spleen, heart, lung, liver, tongue, kidneys, empty GIT and omentum fat.

3 Weight of "Buchada" components in relation to the slaughter weight.

\section{Conclusions}

Cactus pear can replace up to $75 \%$ of the corn in diets for feedlot Santa Ines lambs without harming production, carcass characteristics and production of non-carcass components.

\section{References}

ARAÚJO FILHO, J.T.; COSTA, R.G.; FRAGA, A.B. et al. Efeito de dieta e genótipo sobre medidas morfometricas e não constituintes da carcaça de cordeiros deslanados terminados em confinamento. Revista Brasileira de Saúde e Produção Animal, v.8, n.4, p.394-404, 2007.

BOCCARD , R.; DUMONT, B.L. Etude de la production de la viande chez les ovins. II. Variation de l'importance relative des differents régions corporelles de l'agneau de boucherie. Annales de Zootechnie, v.9, n.4, p.355-365, 1960.

CARVALHO, S.; SILVA, S.F.; CERUTTI, R. et al. Desempenho e componentes do peso vivo de cordeiros submetidos a diferentes sistemas de alimentação. Ciência Rural, v.35, n.3, p.650-655, 2005.

CEZAR, M.F.; SOUZA, W.H. Carcaças ovinas e caprinas: obtenção, avaliação e classificação. Uberaba: Agropecuaria Tropical, 2007. 147p.

CLEMENTINO, R.H.; SOUZA, W.H.; MEDEIROS, A.N. et al. Influência dos níveis de concentrado sobre os cortes comerciais, os constituintes não-carcaça e os componentes da perna de cordeiros confinados. Revista Brasileira de Zootecnia, v.36, n.3, p.681-688, 2007.

COLOMER-ROCHER, F.; MORAND-FEHR, P.; KIRTON, A.H. et al. Métodos normalizados para el estúdio de los caracteres cuantitativos y cualitativos de las canales caprinas y ovinas. Madrid: Ministério da Agricultura, Pesca y Alimentación, 1988. 41p. (Cuadernos 17).

COSTA, R.G.; SANTOS, N.M.; MEDEIROS, A.N. et al. Buchada caprina: características físico-químicas e microbiológicas. Campina Grande: Impressos Adilson, 2007. 93p.

COSTA, R.G.; SANTOS, N.M.; MEDEIROS, A.N. et al. Microbiological evaluation of precooked goat "buchada". Brazilian Journal of Microbiology, v.37, p.362-367, 2006.

FERREIRA, M.A.; VALADARES FILHO, S.C.; COELHO DA SILVA, J.F. et al. Eficiência de utilização da energia metabolizável para ganho de peso e exigências de energia metabolizável e nutrientes digestíveis totais de bovinos F1 Simental x Nelore. Revista Brasileira de Zootecnia, v.28, n.2, p.368-373, 1998.
LÜTTGE, U. Ecophysiology o crassulacean acid metabolism (CAM). Annals of Botany, v.93, p.629-652, 2004.

MEDEIROS, G.R.; CARVALHO, F.F.R.; FERREIRA, M.A. et al Efeito dos níveis de concentrado sobre os componentes nãocarcaça de ovinos Morada Nova em confinamento. Revista Brasileira de Zootecnia, v.37, n.6, p.1063-1071, 2008.

MELO, A.A.S.; FERREIRA, M.A.; VÉRAS, A.S.C. et al. Substituição parcial do farelo de soja por uréia e palma forrageira (Opuntia fícus indica Mill) em dietas para vacas em lactação. I. Desempenho. Revista Brasileira de Zootecnia, v.32, n.3, p.727-736, 2003.

MENDONÇA G.; OSÓRIO J.C.; OLIVEIRA N.M. et al. Morfologia, características e componentes do peso vivo em borregos Corriedale e Ideal. Ciência Rural, v.33, p.351-355, 2003.

NATIONAL RESEARCH COUNCIL - NRC. Nutrient requeriments of sheep. 6.ed. Washington: National Academy Press. 1985. 99p.

OLIVEIRA M.V.M.; PÉREZ J.R.O.; ALVES E.L. Avaliação da composição de cortes comerciais, componentes corporais e órgãos internos confinados e alimentados com dejetos de suínos. Revista Brasileira de Zootecnia, v.31, p.1459-1469, 2002.

OSÓRIO, J.C.S.; OSORIO, M.T.M.; JARDIM, P.O. et al. Métodos para avaliação da produção de carne ovina: in vivo, na carcaça e na carne. Pelotas: Editora e Gráfica Universitária da UFPE - UFPEL, 1998. 107p.

ROSA, T.G.; PIRES, C.C.; SILVA, J.H.S.; MOTTA, O.S. Proporções e coeficientes de crescimento dos não-componentes da carcaça de cordeiros e cordeiras em diferentes métodos de alimentação. Revista Brasileira de Zootecnia, v.31, n.6, p.2290-2298, 2002.

SILVA SOBRINHO, A.G.; AZEVEDO SILVA, A.M.; GONZAGA NETO, S. et al. Sistema de formulação de ração e características in vivo e da carcaça de cordeiros em Confinamento. Agropecuária Científica no Semi-árido, v.1, p.39-45, 2005.

SILVA, L.F.; PIRES, C.C. Avaliações quantitativas e predição das proporções de osso, músculo e gordura da carcaça em ovinos. Revista Brasileira de Zootecnia, v.29, n.4, p.1253-1260, 2000.

UNIVERSIDADE FEDERAL DE VIÇOSA - UFV. Sistema de análises estatísticas e genéticas - SAEG. Viçosa, MG: UFV, 2001. 301p.

WANDERLEY, W.L.; FERREIRA, M.A.; ANDRADE, D.K.B. et al. Palma forrageira (Opuntia fícus-indica Mill) em substituição à silagem de sorgo (Sorgum bicolor, (L.) Moench) na alimentação de vacas leiteiras. Revista Brasileira de Zootecnia, v.31, p.273-281, 2002.

WEISS, W.P. Energy prediction equations for ruminant feeds. In: CORNELL NUTRITION CONFERENCE FEED MANUFACTURES, 61., 1999. Proceedings... Ithaca: Cornell University, 1999. p.176-185. 